\title{
Purification Potentials of Activated Carbon from Chrysophyllum albidum Seed Shells on Petroleum Fractions.
}

\author{
E. Osabohien* and C. Agbanashi \\ Department of Chemistry, Delta State University, Abraka. \\ *Corresponding author’s email: eosabohien@delsu.edu.ng, osabohieneemma@yahoo.com; \\ $+2348036761310$ \\ Received 10 August 2020; accepted 17 August 2020, published online 28 August 2020
}

\begin{abstract}
This research work investigates the use of locally sourced activated carbon as adsorbent in removing impurities and odoriferous substances from some petroleum fractions. The activated carbon was prepared from Crysophyllum abidum (cherry) seed shells. The seed shells were cracked to remove the seeds, washed, dried and pulverized. The powder was carbonized in a furnace at $500{ }^{\circ} \mathrm{C}$, cooled and screened with a $100 \mu \mathrm{m}$ sized sieve. The carbonized powder was impregnated with phosphoric acid and sodium hydroxide in a mixture ratio of $2: 1$, stirred vigorously for activation and kept in an oven to dry at $110{ }^{\circ} \mathrm{C}$ for $2 \mathrm{~h}$. The activated carbon was washed and dried to constant weight, and in comparison with the commercial type were characterized in terms of the moisture, ash, volatile matter contents, $\mathrm{pH}$, bulk density, iodine adsorption number, silica content and percentage yield and gave $2.20 \%, 1.50 \%, 83.50 \%$, $7.15,0.45 \mathrm{~g} / \mathrm{cm}^{3}, 61.01 \mathrm{mg} / \mathrm{g}, 0.25 \%$ and $22.50 \%$ respectively. The activated carbon was applied in the purification of the petroleum fractions (dual purpose kerosene, DPK and premium motor spirit, PMS). The observed density, specific gravity (S.G), initial and final boiling points, flash point, ethanol content and research octane number ( $\mathrm{RON}$ ) of the petroleum fractions before and after the purification process were measured, the results showed that the treated DPK and PMS had improved properties due to the purification potentials of the activated carbons applied on them. The locally sourced activated carbon performed almost as well as the commercial type used, with slight inferiority in RON enhancement.
\end{abstract}

Keywords: Chrysophyllum albidum seed shell, activated carbon, purification and petroleum fractions.

\section{INTRODUCTION}

Activated carbons are useful absorbents with an extensive range of applications that relates to the removal of impurities by adsorption from the liquid or gas phase. They also find use as catalyst support in water treatment, sugar syrup purification, air pollution control as well as in pharmaceuticals and chemical industries. They are also used in first aid process of detoxification owing to its highly porous structure and high surface area and hence its high adsorptive potentials [1-2].

Odoriferous substances and other impurities such as sulphur and colorants which cause environmental pollution are present in liquid fuels. It is therefore needed to develop efficient and affordable processes for the desulphurization and purification of liquid fuels for improved performance and for use as solvents [3-4]. Some earlier reports have made use of liquid extraction processes of removing odour from kerosene [5-6]. Common adsorbents such as activated alumina, clay, limestone or calcium carbonate can be used to remove or reduce odor and color from fuels [3,6].

The use of commercial activated carbon (CAC) may be limited by its high cost which may be due to its source. Agricultural wastes are potential precursors of the abundant supply of low cost activated carbons [7-10].

Chrysophyllum albidum, commonly called cherry is a popular tropical fruit tree and widely distributed in the low land rain forest zones and frequently found in the villages and the fruit is common in rural and urban areas especially during the month of December to April. The fleshy pulp of the fruit (African star apple) is eaten while the seeds are used for local games or 
thrown away as wastes [11-12]. The seed shells can be picked and processed for other applications [13-14].

This study therefore is aimed at utilizing the activated carbon derived from the Chrysophyllum albidum seed shell for removing impurities and coloring agents in petroleum fractions (PMS and DPK) in order to improve their properties and performance in various applications.

\section{MATERIALS AND METHODS}

\section{Materials}

The Chrysophyllum albidum seed shells were picked randomly from domestic areas in Ughelli, Delta State, Nigeria. The commercial activated carbon (CAC) and the petroleum fractions used were sourced from Nigeria National Petroleum Company (NNPC), Warri, Delta state, Nigeria. $\mathrm{Al}$ chemicals used were of analar grades and the pH meter, weighing balance, SB10013, hydrometer and thermometer were got from the laboratory, Department of Chemistry, Delta State University, Abraka. The sieves and thermostat oven, WB20k10004 used were obtained from Petroleum Training Institute (PTI), Effurun, Delta State, Nigeria. Other test equipment and petroleum product testers were standard and obtained from Synergy Mineral Resources Laboratory, Oghara, Delta State, Nigeria.

\section{Methods}

The collected seeds of Chrysophyllum albidum or African tar apple were cracked to obtain the shells which were washed, dried and carbonized at $500{ }^{\circ} \mathrm{C}$ in a muffle furnace for an hour. The sample was pouverized and screened with a sieve of $100 \mu \mathrm{m}$ mesh size. Then, the powdered sample was impregnated with phosphoric acid $\left(\mathrm{H}_{3} \mathrm{PO}_{4}\right)$ and sodium hydroxide $(\mathrm{NaOH})$ in a ratio of 2:1. The paste was stirred for $30 \mathrm{~min}$, air-dried and pyrolyzed at $600{ }^{\circ} \mathrm{C}$ for $30 \mathrm{~min}$ and allowed to cool. The cooled, dried acid-alkali activated sample was then stored in a black polythene bag as fine Chrysophyllum albidum activated carbon (CAAC) powder.

\section{Physicochemical Properties of the Activated Carbons (CAAC and CAC)}

The moisture, ash, volatile matter contents, iodine adsorption number, $\mathrm{pH}$ of aqueous slurry and bulk density using the tamping procedure were determined [10, 15-19].

\section{Purification Process of the Petroleum Fractions (PMS and DPK) using CAAC and CAC}

$500 \mathrm{ml}$ of DPK or PMS sample was measured and poured into the beaker containing $100 \mathrm{~g}$ of the activated carbon (CAAC or CAC) and the mixture was stirred and left for an hour to enable adsorption of impurities to take place. The mixture was then filtered with coned Whatman filter paper. The resulting filtrate, the purified DPK or PMS was observed for its color and odor. The DPK sample was tested for; flash point, initial and final boiling points, observed density and specific gravity while the PMS sample; observed density, specific gravity, initial and final boiling points, research octane number (RON) and percentage ethanol content in comparison with untreated raw DPK and PMS [20-22]. 


\section{RESULTS AND DISCUSSION}

\section{Table 1: Physicochemical properties of activated carbons (CAAC \& CAC)}

\begin{tabular}{lll}
\hline Parameter & CAAC & CAC \\
\hline Moisture content at $105{ }^{0} \mathrm{C}(\%)$ & 2.20 & 2.30 \\
Ash content at $600{ }^{0} \mathrm{C}(\%)$ & 1.50 & 1.40 \\
Volatile matter content at $900{ }^{\circ} \mathrm{C}(\%)$ & 83.50 & 85.20 \\
pH of aqueous slurry & 7.15 & 6.90 \\
Bulk density $\left(\mathrm{g} / \mathrm{cm}^{3}\right)$ & 0.45 & 0.60 \\
Iodine adsorption number $(\mathrm{mg} / \mathrm{g})$ & 61.01 & 78.51 \\
Silica, $\mathrm{SiO}_{2}$ content $(\%)$ & 0.25 & 0.15 \\
Yield $(\%)$ & 22.50 & - \\
\hline
\end{tabular}

The activated carbon obtained from Chrysophyllum albidum has slightly less moisture and higher ash contents as compared to the commercial activated carbon (Table 1). However, the lower the moisture and ash contents the better the adsorption potential [23]. The volatile matter content of $83.50 \%$ is in agreement with Omeiza et al [24]. The $\mathrm{pH}$ of 7.15 , yield of $22.50 \%$ and bulk density of 0.52 $\mathrm{g} / \mathrm{cm}^{3}$ were all in agreement with previous works [23-24]. The results of the observed density and S.G of the PMS and DPK samples were in agreement with that of Riazi [25].

The observed density and S.G of CAAC and CAC treated PMS slightly decreased with higher values of CAC treated which may be due to the presence of ethanol in the CAC treated PMS (Table 3). The observed density and S.G of CAAC and CAC treated DPK decreased slightly as compared to the untreated sample. Ethanol is added to gasoline to lower carbon emissions and make the running of engines more eco-friendly. But ethanol blended fuels if left untreated can cause phase separation when the ethanol absorbs water, it separates from the gasoline by settling at the bottom of the fuel tank. This can cause damage to the fuel and engine systems if not noticed on time. DPR limit for fuel ethanol is still $0.0 \%$, but small quantities are noticed in some fuels which may be due to natural fermentation sources. The untreated PMS in this case has $1.0 \%$ ethanol while the CAC treated had $0.5 \%$ ethanol (Tables 2 and 3). According to Mohammed et al [26], increase in ethanol level of fuels increases research octane number (RON), which is desirable for engines. The RON of CAAC and CAC treated PMS increased by factors of 4.5 and 7.1 respectively as compared to the untreated sample (Tables 2 and 3). The CAC treated PMS had higher RON value may be due to the presence of ethanol which increases RON [26]. The higher the RON of PMS, the less the knocking tendency in automobile engines and the better the fuel quality. The higher the RON value of CAC treated PMS may also be due to higher surface area of CAC with higher iodine adsorption number, it has been observed that the higher the surface area of carbons the higher their efficiencies and performance [14, 27]. 
Table 2: Characteristics of untreated PMS and DPK

\begin{tabular}{lll}
\hline Parameter & PMS & DPK \\
\hline Observed density $\left(\mathrm{kg} / \mathrm{m}^{3}\right)$ & $0.759(-)$ & $0.808(-)$ \\
Specific gravity $\mathrm{S} . \mathrm{G}\left(\mathrm{g} / \mathrm{cm}^{3}\right)$ & $0.766(0.720-0.780)$ & $0.8165(0.775-0.825)$ \\
Ethanol content $(\%)$ & $1.0(0.0)$ & - \\
Research Octane number $(\mathrm{RON})$ & $91(90$ minimum $)$ & - \\
Flash point $\left({ }^{0} \mathrm{C}\right)$ & - & $48(45$ minimum $)$ \\
Initial boiling point $\left({ }^{0} \mathrm{C}\right)$ & $41(42 \max )$ & $160(200 \max )$ \\
Final boiling point $\left({ }^{0} \mathrm{C}\right)$ & $196(210 \max )$ & $278(300 \max )$ \\
\hline
\end{tabular}

( ) values in parenthesis represent Department of Petroleum Resources (DPR) limits for PMS and DPK respectively.

Table 3: Characteristics of CAAC treated PMS \& DPK

\begin{tabular}{|c|c|c|}
\hline Parameter & PMS & DPK \\
\hline Observed density $\left(\mathrm{kg} / \mathrm{m}^{3}\right)$ & $0.751(0.752)$ & $0.782(0.782)$ \\
\hline Specific gravity S.G $\left(\mathrm{g} / \mathrm{cm}^{3}\right)$ & $0.760(0.761)$ & $0.791(0.792)$ \\
\hline Ethanol content (\%) & $0.0(0.5)$ & - \\
\hline Research Octane number (RON) & $95.5(98.1)$ & - \\
\hline Flash point $\left({ }^{0} \mathrm{C}\right)$ & $-\quad-$ & (49) \\
\hline Initial boiling point $\left({ }^{0} \mathrm{C}\right)$ & $40(40)$ & (155) \\
\hline Final boiling point $\left({ }^{\circ} \mathrm{C}\right)$ & $195(193)$ & $(256)$ \\
\hline
\end{tabular}

( ) values in parenthesis are for CAC treated PMS and DPK

The flash points of the CAAC and CAC treated DPK (kerosene) increased by 2 and 1 degrees respectively as compared to the untreated DPK. This is in agreement with previous workdone on kerosene samples [26]. The higher the flash point of DPK, the lower the flammability. And because kerosene (DPK) is used at homes, high flammability may endanger its usuability. The higher the flash point of the kerosene the better the application as fuel and solvent [5].

The initial and final boiling points of treated PMS and DPK samples were lower than the untreated samples (Tables 2 and 3). The CAC treated PMS and DPK samples had lower initial and final boiling pints. This may be due to the finer particle size of CAC sample used. The finer the particle size of activated carbon the higher the surface area and hence, the higher the adsorption and purification potential [27]. The values of the initial and final boiling points of the petrol (PMS) and kerosene (DPK) samples examined in this work are in agreement with those obtained by Riazi [25].

\section{CONCLUSION}

This research work has shown the purification potentials of activated carbon derived from the seed shell of Chrysophyllum albidum in comparison with that of commercial activated carbon (CAC). The improvement of the research octane number RON of the PMS when treatment with the activated carbons (CAAC and CAC), and the lowering of the initial and final boiling points of the PMS and DPK samples are proofs of their purification potentials on the petroleum fractions. This is an indication of removal of impurities such as odoriferous (sulphur compounds) and coloring substances that may be in the petroleum fractions. The CAC performed slightly better in improving the octane rating of PMS, while the locally sourced activated carbon, CAAC, did better in increasing the flash point of DPK, hence, it's comparable to 
the commercial type, CAC in the overall performance. However, optimum performance could be achieved for the locally sourced activated carbon (CAAC) with improved milling and screening of the powder for improved surface area and hence finer particle size.

\section{REFERENCES}

1. M.M. Johns, W.E. Marshall and C.A. Toles (1999). The effect of activation method on the properties of pecan shell activated carbon. J. Chem. Technol. Biotechnol; 74(11), 1037-1044.

2. R.C. Bansal and M. Goyal (2005). Activated carbon adsorption, $1^{\text {st }}$ ed, Taylor and Francis group, CRC Press, Boca Raton, Florida, USA, $520 \mathrm{p}$.

3. C.C. Opara, A.I. Oyom and M.C. Okonkwo (2013), Deodorization of kerosene using activated carbon as adsorbent, Greener $J$. Phy. Sci. 3(2), 070-075.

4. D.M. Mattox (2010), Handbook of physical vapor deposition (PVD) processing, $2^{\text {nd }}$ ed. Elsevier/William Andrew, Oxford. 746 p.

5. A.N. Anozie and S.N. Okafor (2005), Deodorization and dearomatization of kerosene by liquid extraction method, Global J. Engr. Res. 4(1\&2), 23-29.

6. Malcolm Tatum (2003). "How is kerosene deodorized?" www.wisegeek.com, updated July 20, 2020.

7. E.C. Bernardo, R. Eqashira and J. Kawasako (1997). Decolourization of molasses wastewater using activated carbon prepared from cane bagasse, Carbon, 35(9), 1217-1221.

8. C.A. Toles, W.E. Marshall, M.M. Johns, L.A. Wartelle and A. McAloom (2000). Acid activated carbons from almond shells, physical chemical and adsorptive properties and estimated cost of production, Bioresource Technol.71, 87-92.

9. C.E. Gimba, M. Turoti, P.A. Egwaikhide and E.E. Akporhonor (2009). Adsorption of indigo blue dye and some toxic metals by activated carbons from coconut shells. $J$. Chem. Soc. Nigeria, 34(1), 203-210.

10. M. Ahmedna, W.E. Marshall and R.M. Rao (2000). Production of granular activated carbons from selected agricultural by-products and evaluation of their physical, chemical and adsorptive properties. Bioresource Technol. 71 (2), 113-123.

11. I.G. Nodza, A. Abudulhammed and M. B. Abdullahi (2013). A checklist and ethnobotanical assessment of tree species of Abubakar Tafawa Balewa University, Bauchi, Nigeria. Intl. J. Botany, 9(2), 55-63.

12. R.W.J. Keay (1989). Trees of Nigeria. Clavendon press, Oxford, New York.

13. E. Osabohien and S.H.O. Egboh (2007). Cure characteristics and physicomechanical properties of natural rubber filled with the seed shells of cherry (Chrysophyllum albidum). J. Appl. Sci. Environ. Manage. 11(2), 43-48.

14. E. Osabohien (2010), Potential of carbonized cherry seed shell as filler in natural rubber vulcanizates; J. Polym. Mater. 27(4), 389-399.

15. F.E. Okieimen, U.O. Esther and D.O. Ogbeifun (1991). Sorption of cadmium and lead ions on modified groundnut husk. Nigerian J. Technol. Biotechnol. 51.97-99.

16. AOAC (1970), Official methods of analysis, Association of Analytical Chemists, $11^{\text {th }}$ ed. AOAC, Washington, D.C.

17. A.I. Vogel (1964), Textbook of quantitative inorganic analysis, including elementary instrumental analysis, $3^{\text {rd }}$ ed; ELBS and Longmans Green, London.

18. ASTM (2015). Standard methods for testing iodine adsorption number and pH, ASTMD 1510, 1512.

19. F.E. Okiemen, C.O. Okiemen and R.A. Wuana (2007), Preparation and characterization of activated carbon 
from rice husks, J. Chem. Soc. Nigeria.32(1), 126-136.

20. ASTM (2017), standard test methods for density, specific gravity and boiling point of petroleum fractions, ASTMD. 129812b, D5399-09.

21. ASTM (2019), Standard test methods for research octane number (RON) and flash point of petroleum fractions, ASTMD. 2699-19, D93-19.

22. ASTM (2009), Standard test method for denatured fuel ethanol by gas chromatography, ASTM D5501-09.

23. A.I. Okoye (2010), Preparation, characterization and adsorptive evaluation of activated carbon from Telfaira occidentalis and Gambeya albida seed shells, M.Sc. thesis, University of Nigeria, Nsukka, Nigeria.

24. F.S. Omeiza, P.A. Ekwumengbo, J.A. Kagbu and K.O. Isreal (2012), analysis and production of activated carbon from Carica papaya seed by chemical activation, Chem. Technol. Indian J. 6, 33-35.

25. M.R. Riazi (2005), Characterization and properties of petroleum fractions, ASTM International, Technology and Engineering, 407p.

26. E. Mohammed, Y. Mathaniand M.A. Hussen (2011), Effects of ethanolgasoline blends on fuel properties of spark ignition engines; University of Khartoum Engineering Journal, 1, 2228.

27. F. Duarte, F.J. Maldonado-Hodar and L.M. Madeira (2012), Influence of the particle size of activated carbons on their performance as $\mathrm{Fe}$ supports for developing Fenton-like catalysts, Ind. Eng. Chem. Res., 51, 27, 9218-9226. 